\title{
Styrofoam debris as a potential carrier of mercury within ecosystems
}

\author{
Bożena Graca • Magdalena Beldowska • \\ Patrycja Wrzesień • Aleksandra Zgrundo
}

Received: 25 June 2013 / Accepted: 9 September 2013 / Published online: 21 September 2013

(C) The Author(s) 2013. This article is published with open access at Springerlink.com

\begin{abstract}
The present paper falls within the trend of research into interactions between various pollutants emitted anthropogenically into the environment and focuses on mercury and styrofoam debris. The study covers part of the Southern Baltic's drainage area. Apart from styrofoam and beach sand, the research involved mosses, which are bioindicators of atmospheric metal pollution. The research has shown that mercury present in the environment becomes associated with styrofoam debris. The median for mercury concentrations in virgin styrofoam samples $\left(0.23 \mathrm{ng} \mathrm{g}^{-1}\right.$ dry weight (d.w.)) and in beach sand samples $\left(0.69 \mathrm{ng} \mathrm{g}^{-1}\right.$ d.w.) was an order of magnitude lower than in the styrofoam debris (5.20 $\mathrm{ng} \mathrm{g}^{-1}$ d.w.). The highest mercury content observed in styrofoam debris $\left(3,863 \mathrm{ng} \mathrm{g}^{-1}\right.$ d.w.) exceeded the standards for bottom sediment and soil. The binding of mercury to styrofoam debris takes place in water, and presumably also through contact with the ground. A significant role in this process was played by biotic factors, such as the presence of biofilm and abiotic ones, such as solar radiation and the transformations of mercury forms related to it. As a result, mercury content in styrofoam debris underwent seasonal changes, peaking in summertime. Furthermore, the regional changes of mercury content in the studied debris seem to reflect the pollution levels of the environment.
\end{abstract}

Keywords Plastic debris $\cdot$ Styrofoam $\cdot$ Mercury $\cdot$ Biofilm . Baltic Sea

Responsible editor: Vera Slaveykova

B. Graca $(\bowtie) \cdot$ M. Bełdowska $\cdot$ P. Wrzesień $\cdot$ A. Zgrundo Department of Marine Chemistry and Environmental Protection, Institute of Oceanography, University of Gdansk, Al. Marszałka Piłsudskiego 46, 81-378 Gdynia, Poland

e-mail: ocebg@ug.edu.pl

\section{Introduction}

This study carried out on styrofoam (foamed polystyrene) exemplifies the general problem which may be posed by waste materials undergoing quick fragmentation when emitted into the natural environment. Styrofoam is widely used as insulating material in the construction industry, for the production of disposable dishes or packaging, etc. In the study area, it is used to insulate both newly built and existing buildings. Styrofoam has now largely supplanted mineral wool, which had for many years served this purpose. Widespread use results in styrofoam waste of various sizes being deposited in the terrestrial and aquatic ecosystems (Fig. 1). The presence of styrofoam debris in marine environment has been reported for years (Zitko and Hanlon 1991). The relatively quick physical degradation of styrofoam when emitted into the natural environment was not originally planned at the stage of synthesis. However, in recent years, the process has increasingly involved the introduction of polymers, which are designed to fall apart quickly, initiating the decomposition process. Such polymers are now used for the production of, for example, plastic bags, fishing implements, and agricultural foil. They are intended to alleviate the problems caused by the ever-growing consumption of synthetic materials and the consequent increase in the amount of waste. Such materials, however, are highly controversial (e.g. Mucha 2002; Roy et al. 2011). It is known that despite hydrophobic properties and inert character towards aqueous cations of polymers such as polyethylene (PE), polypropylene (PP), or polyvinylchloride (PVC), their fine-grained waste sorb persistent organic pollutants and metals from sea water (e.g. Ashton et al. 2010; Endo et al. 2005; Rios et al. 2007). Furthermore, they are introduced into the food chain on its various levels (Teuten et al. 2007), and there are documented cases in which the concentrations of hydrophobic 

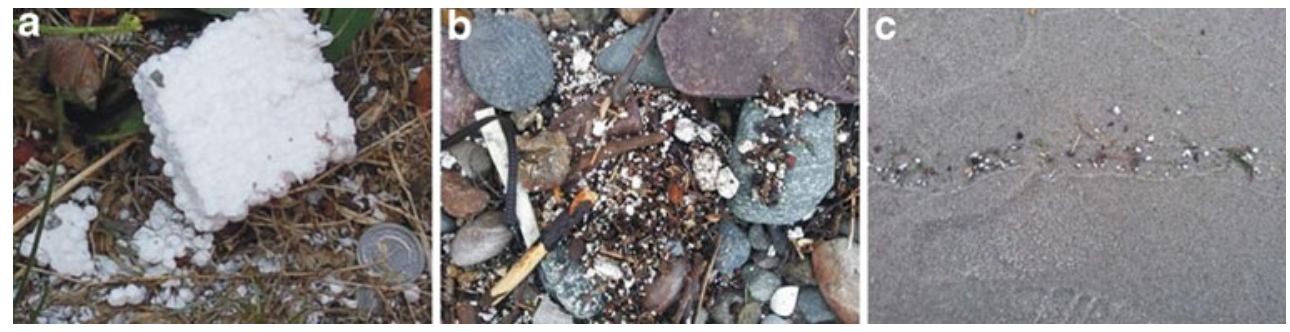

Fig. 1 Styrofoam debris a in a city (photo taken beside a building which was being insulated with styrofoam), b on a beach (photo taken at the foot of a cliff after a storm), and $\mathbf{c}$ on a beach (wave-washed zone, photo taken after a storm)

pollutants increased in organisms that were exposed to the influence of plastic debris (Ryan et al. 1988; Voparil and Mayer 2000).

Unlike PE, PVC, or PP wastes, styrofoam waste already occurs in the fine-grained form on land. As a result, it potentially sorbs pollutants not only from water, but also from air and soil. Moreover, it is characterised by a large surface to weight proportion and a porous structure, which further increases its sorption capacity. It is probable that styrofoam debris is introduced into the alimentary systems of many different water and land organisms. The possibility of styrofoam dust affecting the respiratory system cannot be ruled out either. However, as far as the authors of this study are aware, the interactions between styrofoam debris and other pollutants are not known.

The present paper concentrates on possible interactions between styrofoam debris and mercury, the latter of which is considered to be a global-scale pollutant highly toxic to human health (Schroeder and Munthe 1998; Zahir et al. 2005). Mercury is a natural component of the earth's crust. It is released into the environment from volcanic activity, weathering of rocks, and as a result of human activity (Pirrone and Mason 2009). Anthropopressure, particularly artisanal and small-scale gold mining as well as coal burning is the main cause of mercury releases (UNEP 2013). Once released, mercury undergoes a series of complex transformations and cycles between atmosphere, ocean and land. In the environment, mercury exists in various forms: elemental (or metallic), inorganic (e.g. mercuric chloride) and organic (e.g. methyl- and ethylmercury). This element undergoes bioaccumulation, where its organic forms (such as methylmercury) may become biomagnified in the food chain (Boening 2000). Neurological and behavioural disorders may be observed after inhalation, ingestion, or dermal application of different mercury compounds (WHO 2012). Many publications confirm the neurotoxicity of methyl mercury especially with respect to prenatally exposed children (Hassauer et al. 2012). Toxic effects of mercury on the immune and reproductive system and some other toxic endpoints (cardiovascular and digestive systems, lungs, kidneys, skin, and eyes) have also been reported (WHO 2012; EFSA 2012).

The presented study was carried out in areas of various anthropopressure levels in the Southern Baltic's drainage area (northeastern Poland). Apart from styrofoam debris and beach sand, the research also involved virgin (new) styrofoam as well as mosses, which are bioindicators of atmospheric metal pollution (Rūta and Paliulis 2010). The results of the study are discussed in terms of possible mechanisms of styrofoam debris enrichment in mercury and factors responsible for the variability of this element content.

\section{Materials and methods}

\section{Sampling}

Samples of beach sand, moss, and styrofoam debris were collected in the Southern Baltic's drainage area in northeastern Poland between November 2010 and November 2011. Samples were collected at 13 stations located in three regions (Fig. 2). The first of these regions was along the beaches of the strongly polluted Gulf of Gdansk, between the two cities of Gdansk and Gdynia (stations 1-8) and near the town of Hel (stations 9). The second region (stations 10-12) extended from the village of Debki to Leba along the beaches of the open Baltic Sea. The third area was located inland in the coastal zone of Lake Gołdap (station 13) in the Mazurian Lake District region. Mazuria is a natural region, formed by the last Ice Age in Pleistocene, which is covered by forests and lakes and for which the degree of anthropopression is low. At each station, samples were collected over a stretch of about 1$2 \mathrm{~km}$. Frequency of sampling was dependent on the aim of the research. In order to detect the impact of season on the content of $\mathrm{Hg}$, samples were collected two or three times in every season (autumn, winter, spring, and summer) at all stations located in the Gulf of Gdansk (stations 1-9). In order to detect potential regional variability of $\mathrm{Hg}$ content, the sampling frequency was one or two times per season at all stations (113). Additionally, over a dozen samples of styrofoam debris were collected on the streets of Gdynia, near station 8. At all stations, between 10 and 20 samples of styrofoam debris (not larger than about $2 \mathrm{~cm}$ ) and 10 samples of beach sand as well as moss was sampled. Furthermore, in order to examine the $\mathrm{Hg}$ background in styrofoam, samples of new polymer sourced from a local factory have been prepared for future analysis. 
Fig. 2 Test station sites

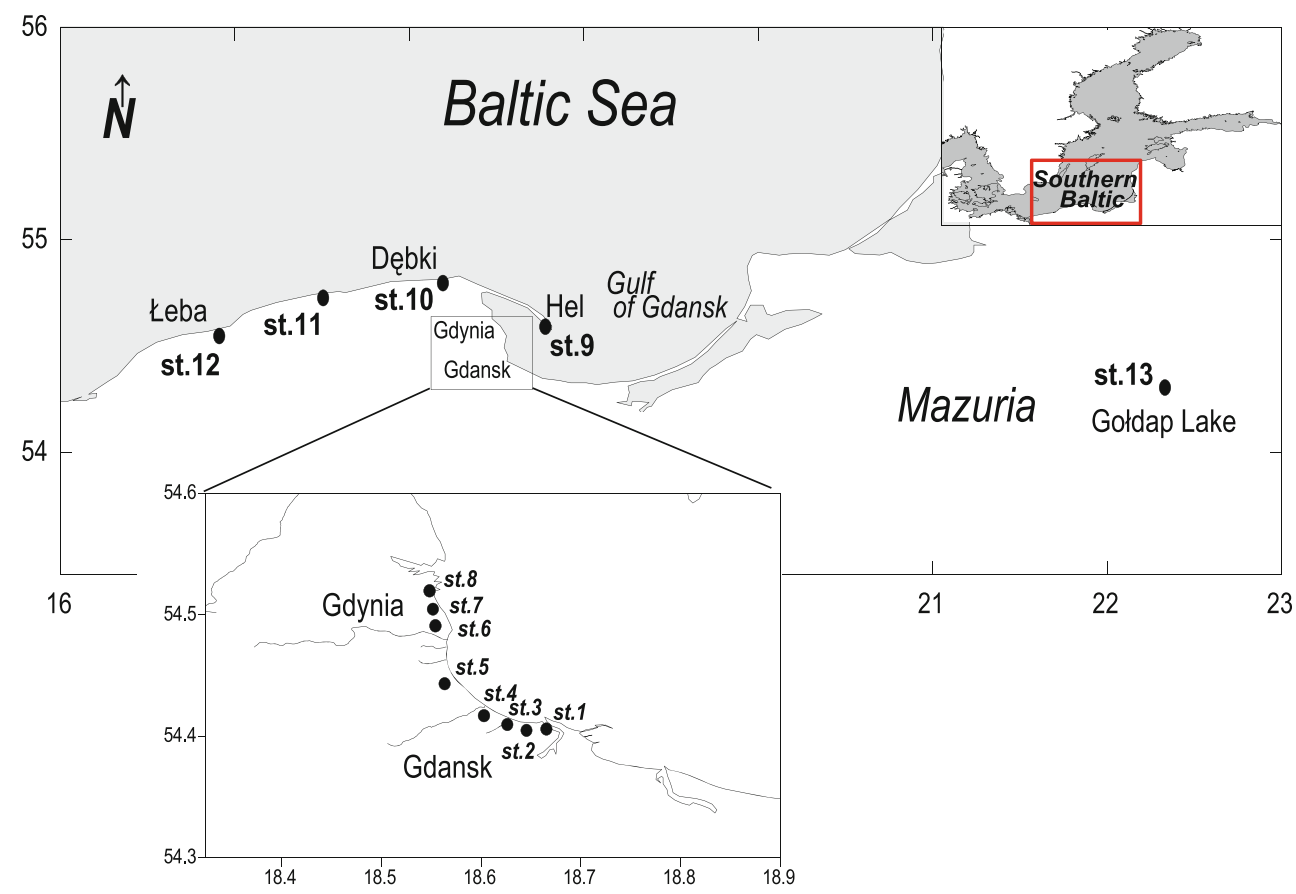

Samples were collected in clean vinyl gloves using plastic tweezers (styrofoam debris and moses) or plastic spatula (beach sand) and were stored frozen in new polyethylene ziplock bags. All equipment used for sampling, sample preparation, and analysis was acid-washed prior to use with a minimum soak of $24 \mathrm{~h}$ in $4 \mathrm{M}$ nitric acid (Merck, analytical reagent grade). After this time, they were rinsed a few times with Milli-Q (MQ) high purity water and dried in an oven $\left(60{ }^{\circ} \mathrm{C}\right)$.

\section{Initial sample preparation}

In the laboratory, the samples were freeze-dried. Dried samples of styrofoam debris were shaken on a sieve (1 mm mesh) in a mechanical shaker for $10 \mathrm{~min}$ in order to remove eventual impurities. Samples of sand and moss were ground in a mortar. Each sample was homogenised with a plastic spatula and approximately $15 \mathrm{mg}$ of styrofoam, $500 \mathrm{mg}$ of beach sand, and $50 \mathrm{mg}$ of mosses were accurately weighed in triplicate and subjected to the total $\mathrm{Hg}$ analysis. In the case of styrofoam samples of larger size (above $5 \mathrm{~mm}$ ), only surface subsamples separated by plastic tweezers were utilised for further analysis.

\section{Analysis}

The Hg content was analysed via pyrolysis where the trap is heated in a stream of oxygen (mercury analyzer AMA 254). In this step, the $\mathrm{Hg}$ was reduced to $\mathrm{Hg}(0)$ and subsequently transferred to the gas phase and detected by conventional amalgamation-thermal desorption-atomic absorption spectroscopy detection. This technique did not require any sample preparation (e.g. extraction/digestion) or manual handling of the sample that could create a risk of contamination (Száková et al. 2004).

Quality control included analysis of samples in triplicates and analysis of certified reference materials. NIMGBW07314 (offshore marine sediment, 0,048 $\mu \mathrm{g} \mathrm{Hg} \mathrm{g}^{-1}$ ) from the National Research Center for Certified Reference Materials (China), standard reference material SRM 2584 (indoor dust, $5.20 \mu \mathrm{g} \mathrm{Hg} \mathrm{g}^{-1}$ ) from the National Institute of Standards and Technology (USA), and BCR-276 (Ulva lactuca, $0.0476 \mu \mathrm{g} \mathrm{Hg} \mathrm{g}^{-1}$, indicative) from the Community Bureau of Reference (Belgium) were used. The analysis of the reference materials proved satisfactory in terms of accuracy and precision of determination. Recoveries equaled 92.5 \pm 9.5 , $95 \pm 3$, and $97 \pm 3 \%$ for NIM-GBW07314, BCR-276, and SRM 2584, respectively. The detection limit, given as the treble standard deviation of mercury content in blank samples, was $0.005 \mathrm{ng} \mathrm{g}^{-1}$.

The qualitative analysis of microorganisms covering the surface of styrofoam debris was conducted using a microscope at $\times 600$ magnification. The statistical analysis of data was conducted using the STATISTICA 10 software. The ANOVA Kruskal-Wallis' test and the post hoc Dunn's test were used. Outlying and extreme values were detected using the Grubbs' test. The hypotheses were tested at a statistical significance level of $p<0.05$. 
Table 1 Descriptive statistics for the concentration values of total mercury (nanogram per gram per dry weight) in virgin styrofoam, styrofoam debris, beach sediment, and moss

${ }^{\text {a }}$ Number of samples analysed

\begin{tabular}{lllllll}
\hline & $n^{\mathrm{a}}$ & Mean $\pm \mathrm{SD}$ & Range $\left(\mathrm{ng} \mathrm{g}^{-1}\right.$ d.w.) & Median & Lower quartile & Upper quartile \\
\hline Virgin styrofoam & 22 & $0.23 \pm 0.17$ & $0.03-0.68$ & 0.23 & 0.07 & 0.33 \\
Styrofoam debris & 214 & $46.8 \pm 299$ & $0.02-3863$ & 5.20 & 3.16 & 10.0 \\
Beach sediment & 163 & $0.85 \pm 0.59$ & $0.15-4.32$ & 0.69 & 0.51 & 0.96 \\
Mosses & 111 & $42.1 \pm 23.1$ & $0.21-126$ & 40.0 & 14.6 & 69.3 \\
\hline
\end{tabular}

\section{Results}

Mercury concentration

Among the analysed abiotic components, styrofoam debris was found to have the highest concentration values (Table 1). The median for mercury concentrations in virgin styrofoam samples (0.23 $\mathrm{ng} \mathrm{g}^{-1}$ dry weight (d.w.)) and in beach sand samples (0.69 $\mathrm{ng} \mathrm{g}^{-1}$ d.w.) was an order of magnitude lower than in the styrofoam debris (5.20 $\mathrm{ng} \mathrm{g}^{-1} \mathrm{~d}$.w.). Mercury content in styrofoam debris was also characterised by the highest range of values and considerable variability compared to the other analysed components, presumably reflecting the heterogeneity of the accumulation process(es).

The median for mercury concentrations in moss was at least 1 order of magnitude higher than the medians in abiotic samples (Table 1). The ANOVA Kruskal-Wallis test indicated a statistically significant influence of the study area on total mercury concentrations in all the analysed environmental components (Fig. 3). The post hoc Dunn's test showed that the observed regional differences in mercury concentrations in moss were attributable to high values in the Gulf of Gdansk, in comparison to those found on the open Baltic coast $(p=0.001)$ and in Gołdap Lake $(p=$ 0.000 ). The situation was analogous in the case of mercury concentrations in beach sand. This means that mercury concentrations in beach sand in the Gulf of Gdansk area were significantly higher than on the open Baltic (post hoc
Dunn's test, $p=0.004$ ) and in Gołdap Lake (post hoc Dunn's test, $p=0.000)$. On the other hand, mercury concentrations in styrofoam debris were similar in the Gulf of Gdansk and in Gołdap Lake (post hoc Dunn's test, $p=$ 0.621 ), and the observed regional differences resulted from low concentration values on the open Baltic compared to the Gulf of Gdansk (post hoc Dunn's test, $p=0.007$ ). Particularly, high values, with strong variability within a particular station, were discovered in styrofoam debris collected along the cliff line of the Gulf of Gdansk (stations 6 7, Table 2).

The influence of the seasons on mercury concentrations in debris, sand, and moss was analysed on the basis of results obtained for samples collected within the Gulf of Gdansk. For other regions, the available amount of data was not representative for each season. The ANOVA Kruskal-Wallis test showed a statistically significant influence of season on mercury concentrations in styrofoam debris and beach sand (Fig. 4a, b). Mercury concentrations in moss, on the other hand, did not vary significantly from season to season (Fig. 4c). In debris, the observed concentration differences resulted from the fact that the values were higher in summer than in winter (post hoc Dunn's test, $p=0.013$ ). For beach sand, significant seasonal differences in $\mathrm{Hg}$ concentrations resulted from low values in summer and high in autumn (post hoc Dunn's test, $p=0.011$ ).

Mercury concentrations in debris collected in the streets ranged from 0.14 to $64.70 \mathrm{ng} \mathrm{g}^{-1}$ d.w. (14.6 $\pm 16.4 \mathrm{ng} \mathrm{g}^{-1}$ d.w., a ANOVA Kruskal-Wallis Test, $\mathrm{p}=0.007$

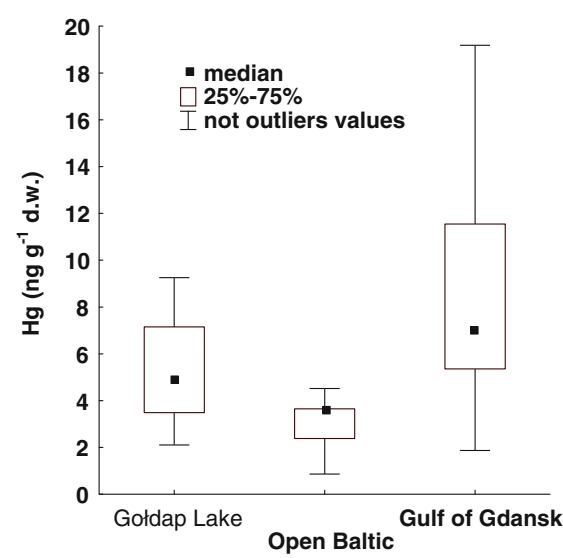

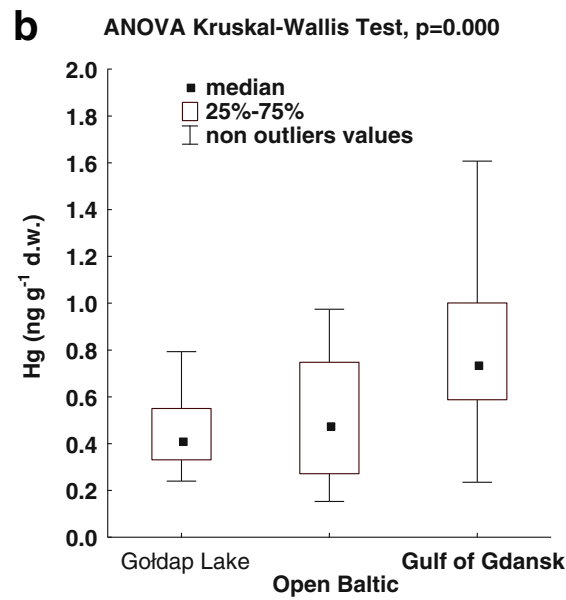

Fig. 3 Regional variations of mercury concentrations in a styrofoam debris, $\mathbf{b}$ beach sand, and $\mathbf{c}$ moss (figure does not show outlying and extreme values)

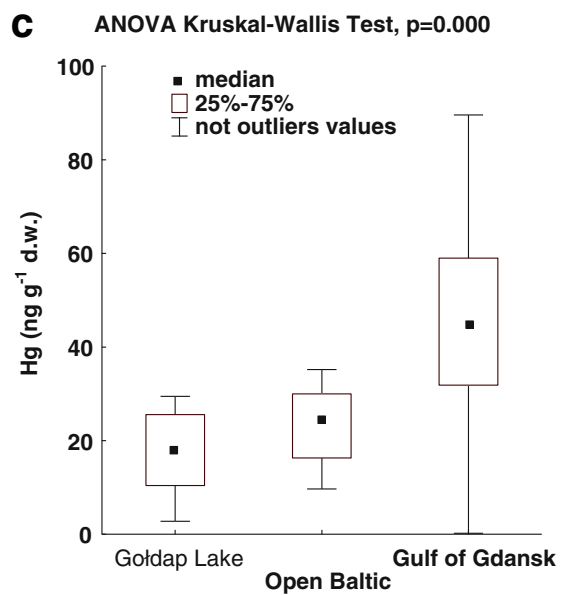

$\underline{2}$ sringer 
Table 2 Statistical characterisation of total mercury concentrations (in nanogram per gram dry weight) in styrofoam debris collected at particular stations

\begin{tabular}{|c|c|c|c|c|c|c|c|}
\hline Area & $n^{\mathrm{a}}$ & Station & Mean \pm SD & Range (ng g ${ }^{-1}$ d.w.) & Median & Lower quartile & Upper quartile \\
\hline \multirow[t]{9}{*}{ Gulf of Gdansk } & \multirow[t]{9}{*}{166} & st.1 & $9.01 \pm 3.85$ & $5.21-16.4$ & 7.75 & 5.89 & 11.5 \\
\hline & & st. 2 & $6.64 \pm 3.51$ & $0.61-13.7$ & 5.88 & 4.14 & 9.35 \\
\hline & & st. 3 & $5.88 \pm 3.54$ & $2.16-11.9$ & 4.30 & 2.96 & 8.15 \\
\hline & & st. 4 & $6.18 \pm 3.98$ & $0.15-14.8$ & 4.74 & 4.08 & 8.11 \\
\hline & & st. 5 & $4.49 \pm 3.99$ & $0.24-15.4$ & 3.42 & 2.95 & 4.28 \\
\hline & & st.6 & $403 \pm 1018$ & $1.92-3863$ & 14.2 & 3.99 & 285 \\
\hline & & st.7 & $100 \pm 196$ & $2.63-778$ & 7.25 & 4.89 & 176 \\
\hline & & st. 8 & $15.9 \pm 50.8$ & $0.02-261$ & 1.61 & 0.47 & 10.5 \\
\hline & & st.9 & $4.87 \pm 2.88$ & $2.11-9.8$ & 4.05 & 2.35 & 7.55 \\
\hline \multirow[t]{3}{*}{ Open Baltic } & \multirow[t]{3}{*}{24} & st.10 & $4.53 \pm 2.37$ & $2.69-8.59$ & 3.57 & 3.20 & 4.62 \\
\hline & & st.11 & $2.14 \pm 1.49$ & $0.18-4.65$ & 1.73 & 1.55 & 2.12 \\
\hline & & st.12 & $8.75 \pm 1.08$ & $7.37-9.98$ & 8.82 & 8.02 & 9.48 \\
\hline Gołdap Lake & 24 & st.13 & $5.96 \pm 2.82$ & $3.44-12.9$ & 5.58 & 3.54 & 6.85 \\
\hline
\end{tabular}

${ }^{\mathrm{a}}$ As in Table 1

median $=9.33 \mathrm{ng} \mathrm{g}^{-1} \mathrm{~d}$.w.). In all seasons, except for winter, mercury concentrations in the street-collected debris were less than those collected on the beach near the city (Fig. 5).

Biofilm on the surface of styrofoam debris

Microscopic observations of styrofoam debris collected on the beach in late summer indicated the presence of bacteria and algae colonies (the latter included diatoms, chlorophytae, and rhodophytae) and unspecified biological forms covering the surface of debris (Fig. 6). Qualitative analysis of microorganisms covering the surface of styrofoam debris give some information about the origins and transport pathways of the sampled material. Species of both marine (Opephora mutabilis and Navicula phylleta) and freshwater diatoms (Psammothidium lauenburgianum) were identified on the surface of the styrofoam.

\section{Discussion}

Factors determining seasonal changes in mercury content

Land is an important source of plastic debris to the marine environment (Andrady 2003, 2011; Thompson et al. 2004). Therefore, higher mercury content in styrofoam debris collected on the beach compared to that collected in the streets (Fig. 5) indicate that mercury binding to the styrofoam debris probably takes place in water. Furthermore, relatively high mercury content in debris from streets compared to values in virgin styrofoam (Table 1) indicates that this process started on land. It would be valuable to calculate enrichment factors for $\mathrm{Hg}$ in polystyrene debris. Such calculation requires data normalisation to a geochemical background and/or amount of organic carbon. This is recommended procedure in monitoring of bottom sediment contamination (e.g. Loring and Rantala 1992). Aluminium a ANOVA Kruskal-Wallis Test, $\mathrm{p}=0.018$

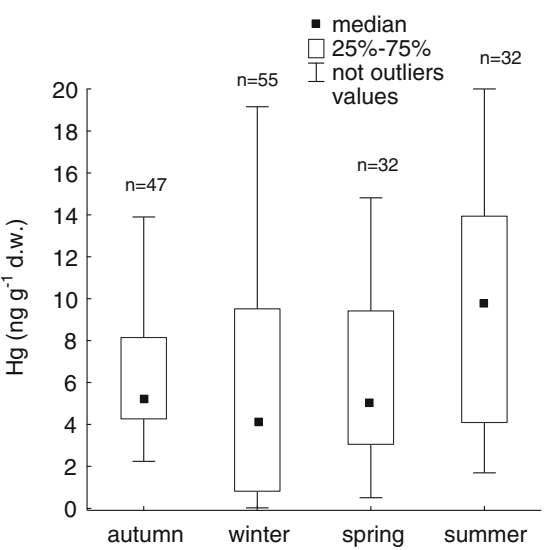

b

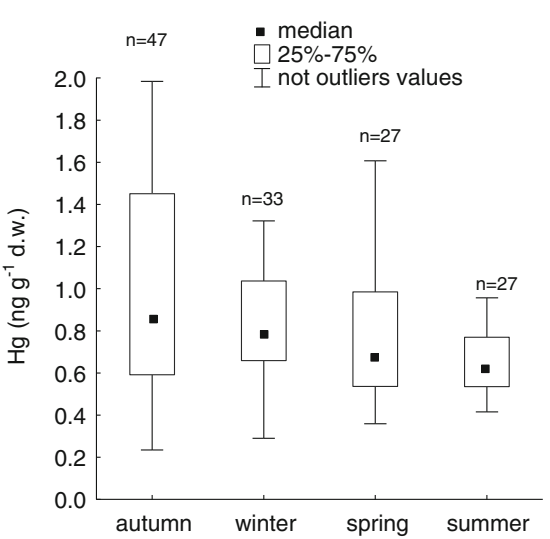

C ANOVA Kruskal-Wallis Test, $p=0.143$

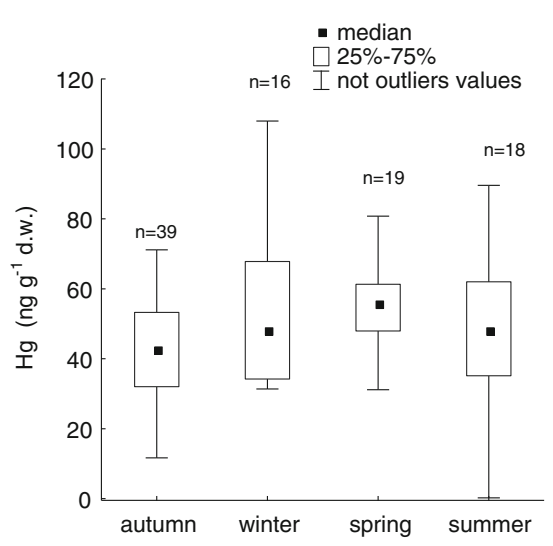

Fig. 4 Characteristics of seasonal changes in mercury content in a styrofoam debris, $\mathbf{b}$ beach sand, and $\mathbf{c}$ moss collected in the Gulf of Gdansk region (figure does not show outlying and extreme values) 


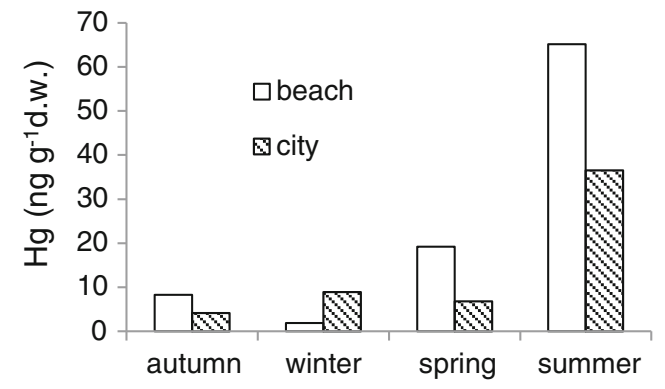

Fig. 5 Mercury concentrations (medians) in styrofoam debris collected on the beach and in the streets of Gdynia in particular seasons

is supposed to normalise for grain size as well as for mineralogical variability (e.g. Covelli and Fontolan 1997) and is mostly used for marine sediment normalisation. However, anthropogenic $\mathrm{Hg}$ has stronger affinity to organic matter than to clays, therefore $\mathrm{Hg}$ concentration should be normalised rather to organic carbon than to $\mathrm{Al}$ content (Herut and Sandler 2006). Since organic carbon is the main component of synthetic polymers, normalisation of $\mathrm{Hg}$ concentration with respect to organic carbon content in styrofoam debris seems to be groundless. An
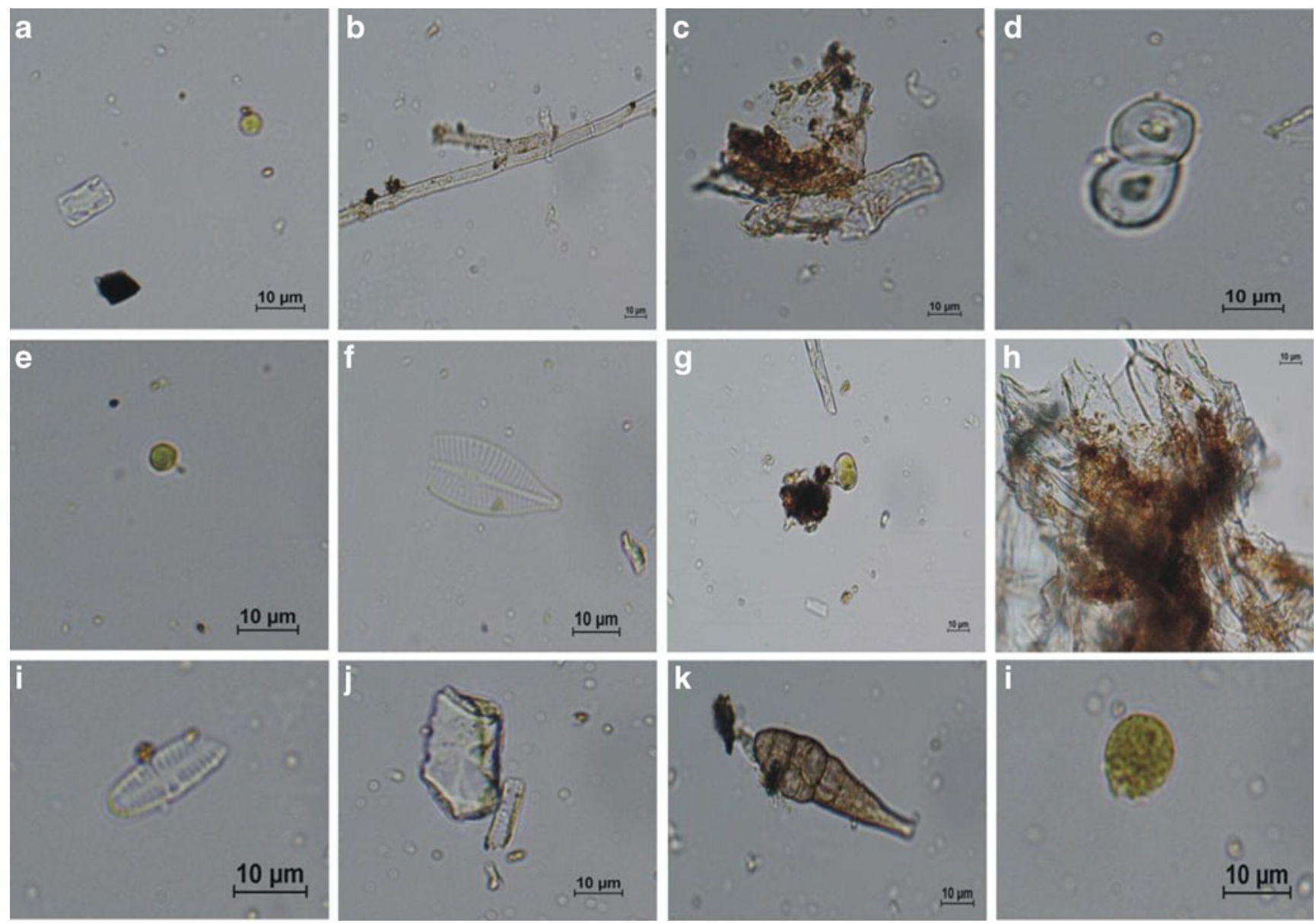

Fig. 6 Microorganisms forming biofilm on styrofoam debris: a diatom shell and a chlorophyta, b chlorophyta thread, $\mathbf{c}$ bacteria colonies, d juvenile biological forms, e chlorophyta, $\mathbf{f}$ Naviculaphylleta diatom, $\mathbf{g}$ additional problem is the purification of debris samples, before chemical analysis, of fine material and biological entities occupying its surfaces. Sieve shaking, as used for the purposes of the present paper, or ultrasonication, as applied by Ashton et al. (2010), is not sufficient. Therefore, future research of metals binding to plastic debris needs an improved sample purification method.

So far, the mechanisms by which metals associate with styrofoam debris are not known. Based on the research of polyethylene pellets, Ashton et al. (2010) and Holmes et al. (2012) suggested that in the marine water, metal cations or complexes are adsorbed onto charged or polar regions as well as onto neutral regions of the surface of the plastic. Charged or polar regions on the surface of a polymer appear, for example, due to the presence of charged contaminants and additives or as a result of photo-oxidative weathering (Mato et al. 2001). The second mechanism of metals association with pellets in the marine environment is co-precipitation with or adsorption onto hydrous oxides of Fe and Mn (Ashton et al. 2010). In the presented study, seasonal variations of mercury concentrations in styrofoam debris (Fig. 4a) and microscopic observations
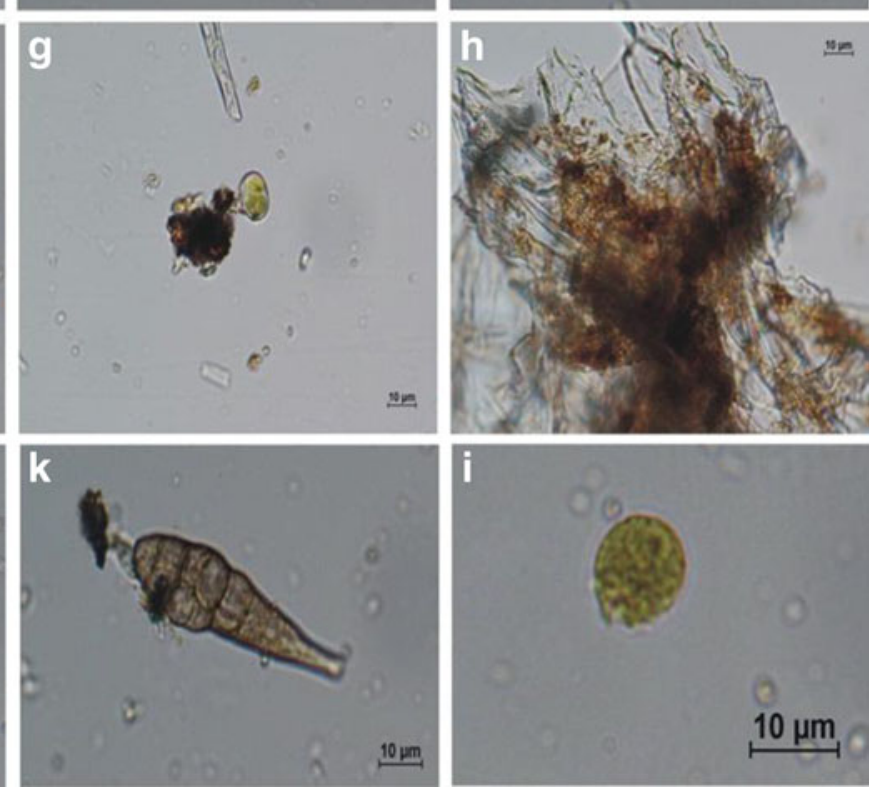

juvenile chlorophyta form, h bacteria colony, i Psammothidium lauenburgianum diatom, $\mathbf{j}$ mineral matter and Opephoramutabilis diatom, $\mathbf{k}$ juvenile Rhodophyta form, $\mathbf{I}$ chlorophyta 
(Fig. 6) show that an important role in the accumulation of this element is probably played by the presence of biofilm. Its role as a natural metal filter is known (Christensen et al. 1985; Kim et al. 1996). A temperature increase is conducive to biofilm growth and stimulates the metabolic activity of microorganisms (Ndiongue et al. 2005), which may explain large mercury concentrations recorded in styrofoam debris during summertime. These high values may also be a result of interactions between mercury compounds, solar radiation, and containing halogens particles emitted from the sea surface. These interactions stimulate mercury deposition during summertime in a coastal zone (Bełdowska et al. 2012). It is also possible that increased solar radiation and higher temperatures in summertime catalyse bonds between mercury and sulphur, to which compounds mercury has an affinity (Jackson 1998). Sulphur compounds are often added to synthetic polymers (Bortel 2008a, b) and are also found in the composition of microorganisms that form the biofilm covering styrofoam surface.

A rise in air temperature and increased solar radiation accelerate the process of mercury re-emission from the soil (Carpi and Lindberg 1998; Zhang et al. 2001). Thus, the relatively small $\mathrm{Hg}_{\text {tot }}$ concentrations found in beach sand in summer (Fig. 4b) could have resulted from this process. In theory, mercury re-emission might also have taken place from surface of the styrofoam. However, mercury accumulation in styrofoam debris is probably stronger than in sand, for which biofilm is likely to be responsible. Its growth is facilitated by the porous structure and large surface area of styrofoam. The seasonal variations in mercury content observed in beach sand (Fig. 4b) were also the result of differences in grain size. The large values obtained in autumn were related to a higher proportion of the fine-grained fraction (macroscopic observation) in some of the samples collected in that period compared to samples collected in other seasons. Clay and organic matter in fine-grained sediment are responsible for its high sorption capacity (Pempkowiak 1997; Ravichandran 2004).

In the present study, seasonal variations of mercury concentrations in moss were analysed on the basis of results obtained in the coastal zone of the sea. It is an area typically characterised by increased sea salt concentrations in the air, due to intensified generation of sea aerosols through wave breaking (Lewandowska and Falkowska 2013). One way in which metals are absorbed by moss from the air is via ion exchange. Sea salt cations compete with heavy metals for the same cation exchange sites in the mosses (Gjengedal and Steinnes 1990). Hence, for example, research done in Germany showed that mercury content in mosses decreased as the distance from the coast increased (Kleppin et al. 2008). It is to be suspected that in the coastal zone of the Gulf of Gdansk sea aerosols have a significant influence on the variability of mercury contents in mosses and play a considerable role in stabilising them in particular seasons (Fig. 4c).
Regional variations in mercury content

The mercury contents obtained for mosses collected in the study area (median, $40 \mathrm{ng} \mathrm{g}^{-1} \mathrm{~d}$.w.) fall into the category of low values in Europe ( $<50 \mathrm{ng} \mathrm{g}^{-1}$ d.w.; Harmens et al. 2008). This is in line with regional differences in industrialisation in Poland, the levels of which are considerably higher in the south than in the north of the country, where the test stations were located.

Regional variations of mercury concentrations in moss and beach sediment (Fig. 3b, c) are in accordance with the results of air pollution investigation carried out in the study area. Within the coastal zone of the Gulf of Gdansk, mercury content in the air is higher than in the Mazuria Lake District and open Baltic (Bełdowska et al. 2003; 2010). The Gulf of Gdansk region is characterised by a larger number of mercury compound emission sources than the other studied areas. Apart from fossil fuel combustion, mercury is brought to the coastal area of the Gulf of Gdansk through ship building, chemical industries, ports and an oil refinery plant, combustion, and dumping of communal/ medical waste as well as sewage sediment (Bełdowska et al. 2003). In the coastal zone of the open Baltic, on the other hand, the significant mercury emission sources are quays, fishing wharfs, fish smokeries, and, notably, individual home hearths. The latter also forms the main emission source of mercury into the atmosphere in the Mazuria Lake District.

As with moss and sand, high concentrations of mercury in styrofoam debris were also typical of the Gulf of Gdansk (Fig. 3a). Statistically, however, the values obtained in that area were not significantly different from those in Gołdap Lake. Moss tends to reflect air pollution, while with styrofoam debris, it is probable that two additional factors come into play: the influence of water and the ground (beach sand/soil). Mercury concentrations for inland waters are usually higher than in the sea. Hence, despite lower atmospheric pollution, coming into contact with soil or lake water could have resulted in the styrofoam samples collected in Gołdap Lake becoming enriched with mercury.

It is worth pointing out the particularly high concentrations in styrofoam debris collected along the cliff line, for these exceeded the standard values for sediment $\left(1,000 \mathrm{ng} \mathrm{g}^{-1}\right)$ and soil (2,000 $\mathrm{ng} \mathrm{g}^{-1}$; Journal of Laws 2002) and testify to the high sorption capacity of styrofoam debris with respect to this element. Such high concentrations probably result from the fact that due to the shape of the terrain, the debris became "trapped" in the coastal zone, where it accumulated mercury for a long time. Photo-oxidative weathering, accumulation of biofilms and chemical precipitates increase the polarity, charge, roughness, porosity, and hydrophilicity of the polymer surface (Artham et al. 2009; Mato et al. 2001). As a result, the reactivity of the surface of aged styrofoam is enhanced. A similar effect (high concentration of contaminants) has been observed for aged, polyethylene pellets (Holmes et al. 2012; Mato et al. 2002; Karapanagioti and Klontza 2008). 


\section{Conclusion}

Styrofoam debris may accumulate mercury compounds present in the environment. The total mercury content found in the debris from beaches was an order of magnitude higher than in the virgin styrofoam and in beach sand. The highest content of mercury in styrofoam debris exceeded the values of standards for bottom sediment (1,000 $\left.\mathrm{ng} \mathrm{g}^{-1}\right)$ and soil $\left(2,000 \mathrm{ng} \mathrm{g}^{-1}\right)$. Therefore styrofoam debris should be treated as a potential carrier of mercury within ecosystems. These findings seem to be especially important in the context of bioaccumulation and biomagnification of mercury, as well as the introduction of plastic debris into the food chain by many aquatic and probably also terrestrial organisms.

The binding of mercury to styrofoam debris takes place in water and presumably also through contact with the ground. An important role is played by the complex influence of biotic factors, such as the presence of biofilm, as well as abiotic factors such as solar radiation and mercury transformations related to it. As a result, mercury concentrations in styrofoam debris undergo seasonal and regional changes. High concentrations are typical in the summer, while regional variability seems to reflect the pollution level of the environment. Thus, the lowest mercury concentrations were found in debris collected along the open Baltic coast, where air and water pollution in mercury is lower than in the Gulf of Gdansk and Gołdap Lake. The highest mercury concentrations were obtained from debris collected along the cliff line of the Gulf of Gdansk, where, due to the shape of the coastline, debris had probably lingered for a long period of time.

This study conducted on styrofoam and mercury exemplifies the general problem which may be posed by waste materials undergoing quick fragmentation when emitted into the environment. A thorough understanding of the mechanisms of metal uptake onto styrofoam and other plastic debris, however, would require further studies, both environmental and experimental.

Open Access This article is distributed under the terms of the Creative Commons Attribution License which permits any use, distribution, and reproduction in any medium, provided the original author(s) and the source are credited.

\section{References}

Andrady AL (2003) Environmental primer. Plastics and the environment. Wiley, New Jersey

Andrady AL (2011) Microplastics in the marine environment. Mar Pollut Bull 62:1596-1605

Artham T, Sudhakar M, Venkatesan R, Madhavan Nair C, Murty KVGK, Doble M (2009) Biofouling and stability of synthetic polymers in sea water. Int Biodeterior Biodegrad 63:884-890

Ashton K, Holmes L, Turner A (2010) Association of metals with plastic production pellets in the marine environment. Mar Pollut Bull 60: 2050-2055
Bełdowska M, Falkowska L, Marks R (2003) Total gaseous mercury over the coastal zone of the gulf of Gdańsk. Oceanol Hydrobiol Stud 32:3-18

Bełdowska M, Saniewska D, Falkowska L, Lewandowska A, Bruszewski H, Degórska A, Sniezek T, Sienicka P (2010) Rtęć w aerozolach w rejonie puszczy i w strefie brzegowej morza. In: Falkowska L (ed) Rtęć w środowisku, identyfikacja zagrożeń dla zdrowia człowieka. Fundacja Rozwoju UG, Gdańsk, pp 11-23 (in polish)

Bełdowska M, Saniewska D, Falkowska L, Lewandowska A (2012) Mercury in particulate matter over Polish zone of the southern Baltic Sea. Atmos Environ 46:397-404

Boening DW (2000) Ecological effects, transport, and fate of mercury: a general review. Chemosphere 12:1335-1351

Bortel K (2008a) Środki pomocnicze stosowane w przetwórstwie tworzyw polimerowych. Część 1. Przetwórstwo Tworzyw 5:33-137, in polish

Bortel K (2008b) Środki pomocnicze stosowane w przetwórstwie tworzyw polimerowych. Czesść 2. Przetwórstwo Tworzyw 6:148153 (in polish)

Carpi A, Lindberg SE (1998) Application of a Teflon dynamic flux chamber for quantifying soil mercury flux: tests and results over background soils. Atmos Environ 32(5):873-882

Christensen BE, Kjosbakken J, Smidsrød O (1985) Partial chemical and physical characterization of two extracellular polysaccharides produced by marine, periphytic Pseudomonas sp. strain NCMB 2021. Appl Environ Microbiol 50:837-845

Covelli S, Fontolan G (1997) Application of a normalization procedure in determining regional geochemical baselines. Environ Geol 30:34-45

EFSA (2012) Panel on Contaminants in the Food Chain (CONTAM); Scientific opinion on the risk for public health related to the presence of mercury and methylmercury in food. EFSA Journal 10(12):2985. pp. 241. www.efsa.europa.eu/efsajournal

Endo S, Takizawa R, Okuda K, Takada H, Chiba K, Kanehiro H et al (2005) Concentration of polychlorinated biphenyls (PCBs) in beached resin pellets: variability among individual particles and regional differences. Mar Pollut Bull 50:1103-1114

Gjengedal E, Steinnes E (1990) Uptake of metal ions in moss from artificial precipitation. Environ Monit Assess 14(1):77-87

Harmens H, Norris D et al (2008) Spatial and temporal trends in heavy metal accumulation in mosses in Europe (1990-2005), United Kingdom. RMG Design \& Print Limited, Cambridgeshire

Hassauer M, Kaiser E, Schneider K, Schuhmacher-Wolz U (2012) Collated literature on toxicity data for mercury in experiments on animals and humans, part I. Supporting publications 2012:EN-297, pp 360. www.efsa.europa.eu/publications

Herut B, Sandler A (2006) Normalization methods for pollutants in marine sediments: review and recommendations for the Mediterranean. UNEP/MAP (IOLR report H18/2006): New York, pp 23. http:// www.sednet.org/download/0604_herut_and_sandler_report.pdf

Holmes LA, Turner A, Thompson R $\bar{C}(201 \overline{2})$ Adsorption of trace metals to plastic resin pellets in the marine environment. Environ Pollut $160(1): 42-48$

Jackson TA (1998) Mercury in aquatic ecosystem. In: Langston J, Bebiano MJ (eds) Metal metabolism in aquatic environment. Chapman \& Hall, London, pp 178-249

Journal of Laws (2002) Nr 55 item 498 of 14.05 .2002

Karapanagioti HK, Klontza I (2008) Testing phenanthrene distribution properties of virgin plastic pellets and plastic eroded pellets found on Lesvos Island beaches (Greece). Mar Environ Res 65:283-290

Kim SY, Kim JH, Kim CJ, Oh DK (1996) Metal adsorption of the polysaccharide produced from Methlobacterium organophilum. Biotechnol Lett 18:1161-1164

Kleppin L, Pesch R, Schröder W (2008) CHAID Models on boundary conditions of metal accumulation in mosses collected in Germany 1990, 1995 and 2000. Atmos Environ 42(21):5220-5231

Lewandowska A, Falkowska L (2013) Sea salt in aerosols over the Southern Baltic. Part 1. The generation and transportation of marigenic particles. Oceanologia 55(2):279-298 
Loring DH, Rantala RTT (1992) Manual for the geochemical analyses of marine sediments and suspended particulate matter. Earth Sci Rev 32:2350283

Mato Y, Isobe T, Takada H, Kanehiro H, Ohtake C, Kaminuma T (2001) Plastic resin pellets as a transport medium for toxic chemicals in the marine environment. Environ Sci Technol 35:318-324

Mato Y, Takada H, Zakaria MP, Kuriyama Y, Kanehiro H (2002) Toxic chemicals contained in plastic resin pellets in the marine environment - spatial difference in pollutant concentrations and the effects of resin type. Kankyo Kagakukaishi 15:415-423

Mucha M (2002) Polimery a ekologia. Wydawnictwo Politechniki Łódzkiej, Łódź, in Polish

Ndiongue S, Huck PM, Slawson RM (2005) Effects of temperature and biodegradable organic matter on control of biofilms by free chlorine in a model drinking water distribution system. Water Res 39:953-964

Pempkowiak J (1997) Zarys Geochemii Morskiej. Wydawnictwo Uniwersytetu Gdańskiego, Gdańsk, in Polish

Pirrone N, Mason R (2009) Mercury fate and transport in the global atmosphere. Springer, Dordrecht

Ravichandran M (2004) Interactions between mercury and dissolved organic matter-a review. Chemosphere 55:319-331

Rios LM, Moore C, Jones PR (2007) Persistent organic pollutants carried by synthetic polymers in the ocean environment. Mar Pollut Bull 54: $1230-1237$

Roy KP, Hakkarainen M, Varma IK, Albertsson AC (2011) Degradable polyethylene: fantasy or reality. Environ Sci Technol 45(10):4217-4227

Rūta B, Paliulis D (2010) Research into heavy metals pollution of atmosphere applying moss as bioindicator: a literature review. Environ Res Eng Manag 4(54):26-33
Ryan PG, Connell AD, Gardner BD (1988) Plastic ingestion and PCBs in seabirds: is there a relationship? Mar Pollut Bull 19:174-176

Schroeder WH, Munthe J (1998) Atmospheric mercury - an overview. Atmos Environ 32(5):809-822

Száková J, Kolihová D, Miholová D, Mader P (2004) Single-purpose atomic absorption spectrometer AMA-254 for mercury determination and its performance in analysis of agricultural and environmental materials. Chem Pap 58(50):311-315

Teuten EL, Rowland SJ, Galloway TS, Thompson RC (2007) Potential for plastics to transport hydrophobic contaminants. Environ Sci Technol 41:7759-7764

Thompson RC, Olsen Y, Mitchell RP, Davis A, Rowland SJ, John AWG et al (2004) Lost at sea: where is all the plastic? Science 304(5672):838

UNEP (2013) Global mercury assessment 2013: sources, emissions, releases and environmental transport. UNEP Chemicals Branch: Geneva, Switzerland. http://www.unep.org/PDF/PressReleases/ GlobalMercuryAssessment2013.pdf

Voparil IM, Mayer LA (2000) Dissolution of polycyclic aromatic hydrocarbons into the lugworm's (Arenicola marina) digestive fluids. Environ Sci Technol 34:1221-1228

WHO (2012) Mercury and health. Fact sheet no 361. April 2012. http:// www.who.int/mediacentre/factsheets/fs361/en/

Zahir F, Rizwi SJ, Haq SK, Khan RH (2005) Low dose mercury toxicity and human health. Environ Toxixol Pharmacol 20:351-360

Zhang H, Lindberg SE, Marsik F, Keeler GJ (2001) Mercury air/surface exchange of background soils of the Tahquamenon river watershed in the Michigan Upper Peninsula. Water Air Soil Pollut 126:151-169

Zitko V, Hanlon M (1991) Another source of pollution by plastics: skin cleaners with plastic scrubbers. Mar Pollut Bull 22:41-42 